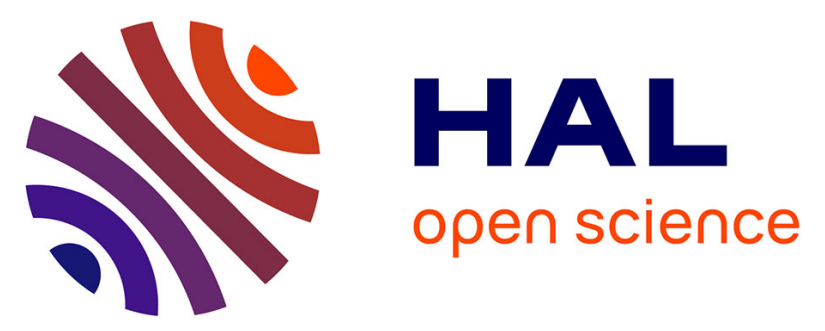

\title{
Dark skin phototype is associated with more severe ocular complications of Stevens--Johnson syndrome and toxic epidermal necrolysis
}

D. Thorel, A. Delcampe, S. Ingen-housz-oro, C. Hajj, E. Gabison, O. Chosidow, P. Wolkenstein, G. Royer, K. Ezzedine, M. Muraine, et al.

\section{To cite this version:}

D. Thorel, A. Delcampe, S. Ingen-housz-oro, C. Hajj, E. Gabison, et al.. Dark skin phototype is associated with more severe ocular complications of Stevens-Johnson syndrome and toxic epidermal necrolysis. British Journal of Dermatology, 2019, 181 (1), pp.212-213. 10.1111/bjd.17627 . hal02316578

\section{HAL Id: hal-02316578}

https://hal-normandie-univ.archives-ouvertes.fr/hal-02316578

Submitted on 16 Oct 2019

HAL is a multi-disciplinary open access archive for the deposit and dissemination of scientific research documents, whether they are published or not. The documents may come from teaching and research institutions in France or abroad, or from public or private research centers.
L'archive ouverte pluridisciplinaire HAL, est destinée au dépôt et à la diffusion de documents scientifiques de niveau recherche, publiés ou non, émanant des établissements d'enseignement et de recherche français ou étrangers, des laboratoires publics ou privés. 
DR SASKIA INGEN-HOUSZ-ORO (Orcid ID : 0000-0002-5383-7096)

DR CARLA HAJJ (Orcid ID : 0000-0002-8954-499X)

DR KHALED EZZEDINE (Orcid ID : 0000-0002-5468-4589)

DR JULIE GUEUDRY (Orcid ID : 0000-0002-8592-3810)

Article type : Research Letter

\section{DARK SKIN PHOTOTYPE IS ASSOCIATED WITH MORE SEVERE OCULAR COMPLICATIONS OF STEVENS-JOHNSON SYNDROME AND TOXIC EPIDERMAL NECROLYSIS}

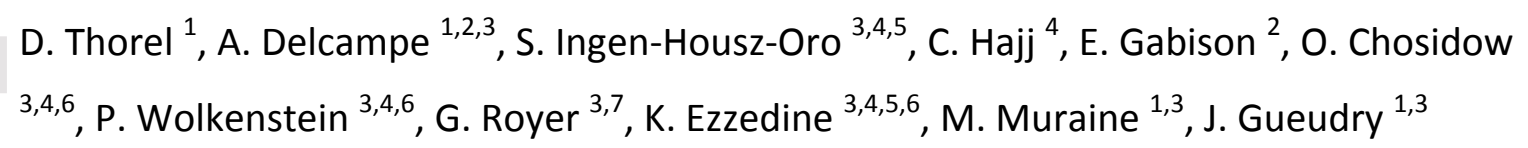

${ }^{1}$ Department of Ophthalmology - Charles Nicolle University Hospital, Rouen, France

${ }^{2}$ Department of Ophthalmology -Bichat Claude Bernard Hospital, Paris, France.

${ }^{3}$ French National Reference Center for Toxic Bullous Dermatoses, Créteil, France

${ }^{4}$ Dermatology Department, AP-HP, Henri Mondor Hospital, Créteil, France

${ }^{5}$ EA7379 EpiDermE (Epidemiologie en Dermatologie et Evaluation des Thérapeutiques), Université Paris-Est Créteil Val de Marne (UPEC), Créteil, France

${ }^{6}$ Université Paris-Est Créteil Val de Marne (UPEC), Créteil, France

${ }^{7}$ Ophthalmology Department, AP-HP, Henri Mondor Hospital, Créteil, France

This article has been accepted for publication and undergone full peer review but has not been through the copyediting, typesetting, pagination and proofreading process, which may lead to differences between this version and the Version of Record. Please cite this article as doi: $10.1111 /$ bjd.17627

This article is protected by copyright. All rights reserved. 
Correspondence and reprint requests to:

Dr Julie Gueudry

Department of Ophthalmology

Charles Nicolle Hospital

22 Boulevard Gambetta

76031 ROUEN - FRANCE

Tel: (33) $232888057 \quad$ Fax: (33) 232888046

E-mail: julie.gueudry@chu-rouen.fr

Funding: none

Conflicts of interest: none

Dear Editor,

Stevens-Johnson syndrome (SIS) and toxic epidermal necrolysis (TEN) are acute severe skin reactions with extensive apoptosis of the epidermis and mucous membranes. ${ }^{1}$ Ocular involvement occurs in up to $75 \%$ of patients at the acute phase, described as mild, moderate and severe involvement and may result in long-term severe sequelae with dryness, photophobia, cicatrising conjunctivitis complicated with corneal vascularisation and scarring, which may result in severe visual loss. ${ }^{2,3}$ The acute management of SJS/TEN ocular complications has not been codified. The place of amniotic membrane transplantation remains to be specified, especially for patients with the most severe complications. ${ }^{4}$ Ophthalmological rehabilitation strategy may include the use of scleral lenses, which significantly improve visual acuity and quality of life in SJS/TEN patients. ${ }^{5}$

As previously described, the prevalence of long-term visual disability increases with the initial ocular severity, ${ }^{2,6}$ but other risk factors have been poorly described. Considering the abnormal wound-healing process in dark phototypes (Fitzpatrick phototype scale V-VI), we hypothesized that the same pathological profibrotic process could involve the ocular

This article is protected by copyright. All rights reserved. 
surface. The aim of the study was to evaluate if SJS/TEN patients with dark phototypes (VVI) had more severe ocular sequelae than light phototypes (I to IV).

We retrospectively included SJS/TEN patients with late ocular complications referred to the specific scleral contact lens consultation of the Ophthalmology Departments of Rouen and Bichat-Claude Bernard University Hospitals, France, from 2003 to 2016. Patient phototypes were determined from eyelid pigmentation on slit lamp photographies by dermatologist-trained ophthalmologists. Exclusion criteria were lack of data (i.e. absence of photograph and/or detailed ophthalmological results) or non-discriminatory phototype slit lamp photographies. Clinical and ophthalmological data from patient charts were described according to their skin phototype (I to IV versus V-VI). With regard to ophthalmological complications, we specifically detailed the severity of visual acuity loss defined by a visual acuity without scleral lens of $\leq 20 / 200$ in the worst eye and the presence of other severe sequelae, i.e severe cicatrising conjunctivitis (symblepharons, trichiasis/distichiasis), corneal punctate epithelial erosions, corneal vascularisation and corneal ulceration (Fig.1).

The study was approved by the local Institutional Review Board (E2018-62).

Among 90 patients examined during the study period, 21 were excluded and 69 (41 female) were included. Median age was 45 years (range, 17 - 79). There was no difference in patients' characteristics regarding age and sex. Forty-six patients had phototypes I-IV (67\%) and 23 patients had phototypes V-VI (33\%). The median duration between the acute phase and the specialised contact lens consultation was 6 years (range, 6 months to 44 years). A visual acuity of $\leq 20 / 200$ in the worst eye was significantly more frequent in phototypes V-VI $(18 / 23 ; 78 \%)$ than in phototypes I-IV $(23 / 46 ; 50 \%$, chi-squared test, $p=0.037)$.

Symblepharons and trichiasis/distichiasis were significantly more frequent in phototypes VVI $(13 / 23 ; 56 \%$ vs $10 / 46 ; 22 \%$, chi-squared test, $p=0.006)$. Corneal ulceration was also more frequent in phototypes V-VI $(16 / 23 ; 48 \%$ vs $25 / 46 ; 24 \%$, chi-squared test, $p=0.05)$. However, there was no significant difference between phototypes for corneal punctate epithelial erosions (20/23; $69 \%$ vs $31 / 46 ; 54 \%$, chi-squared test, $p=0.3)$ and corneal vascularisation $(11 / 23 ; 87 \%$ vs $11 / 46 ; 67 \%$, chi-squared test, $p=0.1)$.

This article is protected by copyright. All rights reserved. 
Our study suggests for the first time that late ocular complications of SJS/TEN (visual loss, severe cicatrising conjunctivitis) could be more severe in phototypes $\mathrm{V}-\mathrm{VI}$, suggesting that dark phototypes could favor a pro-fibrotic process in the ocular surface. However, despite a higher risk of hypertrophic or keloid scars in dark phototypes, there are no published studies highlighting this complication in SJS/TEN. It has been shown that superficial skin injuries that primarily affect the epidermis might have different consequences on remodelling than deeper injuries involving the dermis. ${ }^{7}$ This might explain the scarcity of keloid scars in SJS/TEN as the disease primarily affects the epidermis. In contrast, in SJS/TEN, persistent conjunctival inflammation due to secondary reaction from ocular surface failure induced during the acute phase such as loss of goblet cells, accessory lacrimal glands, and secretory ductules of the main lacrimal glands and meibomian gland orifices, can induce progressively irreversible cicatricial changes. ${ }^{8}$ Our study has several limitations due to its retrospective design and the ophthalmological recruitment of patients. The time between the acute disease and the first consultation for scleral lens fitting may vary. The characteristics and management of the acute phase were unknown as well as the presence of skin sequelae (especially keloid scars). However, considering the rarity of SJS/TEN, we included a large number of patients and had a standardized ophthalmological examination.

In conclusion, phototype should be considered as a factor associated for late severe ocular complications of SJS/TEN.

\section{Acknowledgements}

The authors are grateful to Nikki Sabourin-Gibbs for her help in editing the manuscript.

This article is protected by copyright. All rights reserved. 


\section{References:}

1 Duong TA, Valeyrie-Allanore L, Wolkenstein P et al. Severe cutaneous adverse reactions to drugs. Lancet 2017; 390: 1996-2011.

2 Gueudry J, Roujeau JC, Binaghi M et al. Risk factors for the development of ocular complications of Stevens-Johnson syndrome and toxic epidermal necrolysis. Arch Dermatol 2009; 145: 157-62.

3 Power WJ, Ghoraishi M, Merayo-Lloves J et al. Analysis of the acute ophthalmic manifestations of the erythema multiforme/Stevens-Johnson syndrome/toxic epidermal necrolysis disease spectrum. Ophthalmology 1995; 102: 1669-76.

4 Sharma N, Thenarasun SA, Kaur M et al. Adjuvant Role of Amniotic Membrane Transplantation in Acute Ocular Stevens-Johnson Syndrome: A Randomized Control Trial. Ophthalmology 2016; 123: 484-91.

5 Tougeron-Brousseau B, Delcampe A, Gueudry J et al. Vision-related function after scleral lens fitting in ocular complications of Stevens-Johnson syndrome and toxic epidermal necrolysis. Am J Ophthalmol 2009; 148: 852-9 e2.

6 Sotozono C, Ueta M, Nakatani E et al. Predictive Factors Associated With Acute Ocular Involvement in Stevens-Johnson Syndrome and Toxic Epidermal Necrolysis. Am J Ophthalmol 2015; 160: 228-37 e2.

7 van Geel N, Speeckaert R, Taieb A et al. Koebner's phenomenon in vitiligo: European position paper. Pigment Cell Melanoma Res 2011; 24: 564-73.

8 Kawasaki S, Nishida K, Sotozono $C$ et al. Conjunctival inflammation in the chronic phase of Stevens-Johnson syndrome. Br J Ophthalmol 2000; 84: 1191-3.

Figure 1: Late severe ocular complications of TEN in a phototype VI patient showing corneal scarring and neovascularisation (white arrow). (a) Severe cicatrising conjunctivitis as severe ocular complications of TEN in a phototype VI patient showing corneal neovascularisation (white arrow) and symblepharon (black arrow). (b) Late severe ocular complications of TEN in a light phototype patient showing corneal neovascularisation (white arrow) and corneal ulcer (black arrow). (c) Severe cicatrising conjunctivitis as severe ocular complications of TEN in a light phototype patient showing corneal neovascularisation (white arrow) and trichiasis (black arrow). (d)

This article is protected by copyright. All rights reserved. 

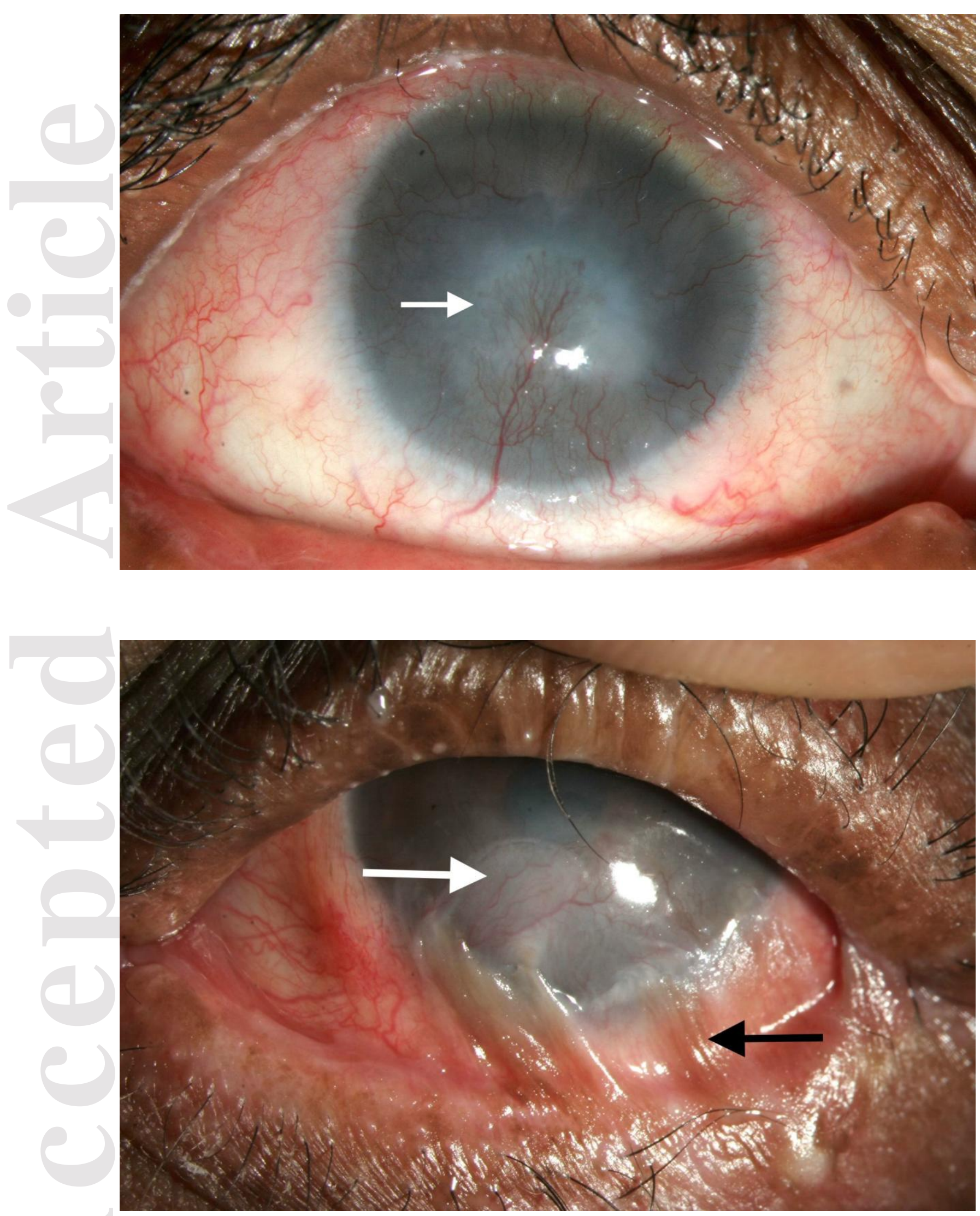

This article is protected by copyright. All rights reserved. 

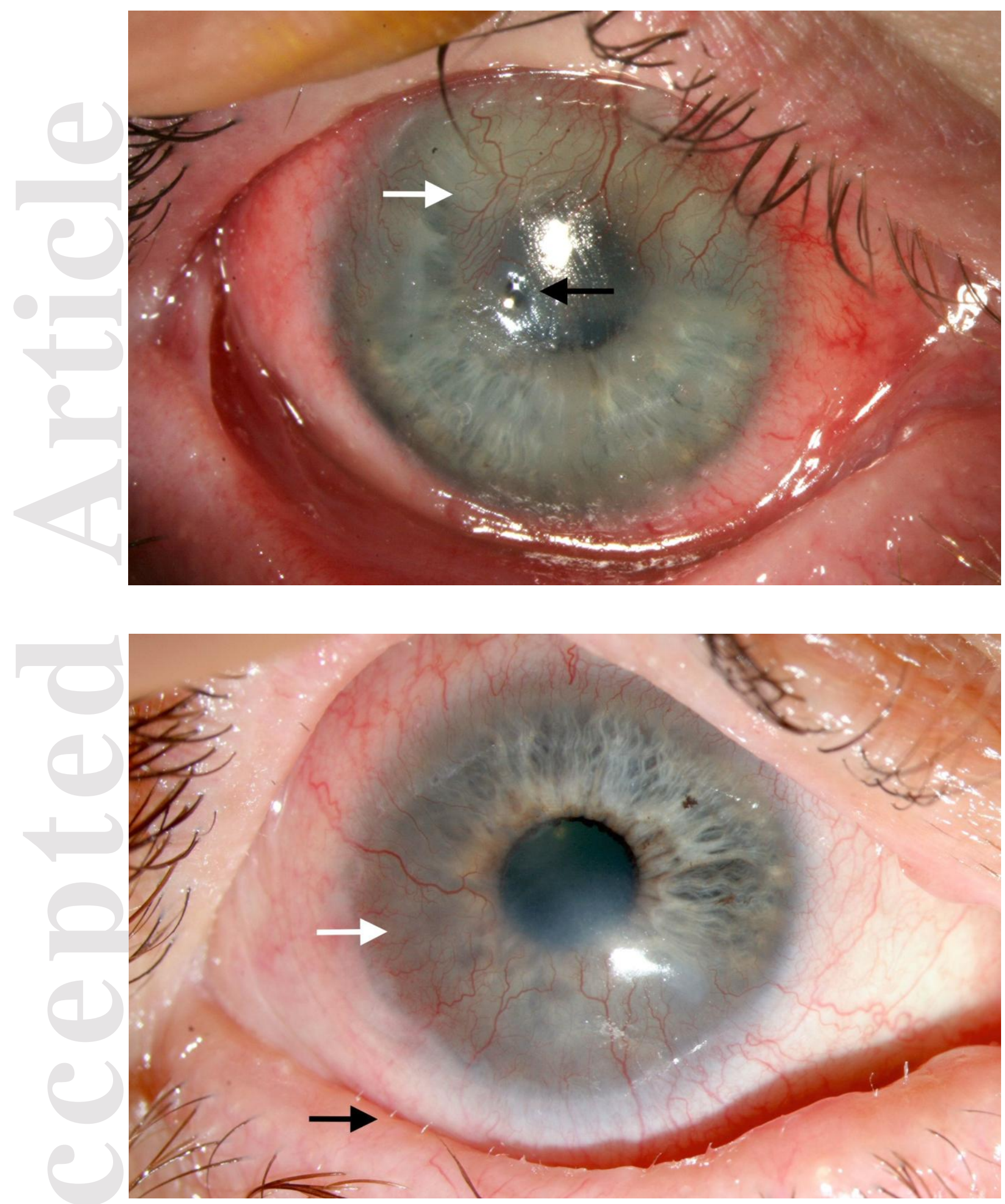

This article is protected by copyright. All rights reserved. 